Volume 5 Issue 2, June 2018

\title{
The Authority Of Public Notary In The Making Of Deregistration Agreement Of Mortgage Right
}

\author{
Gholib Ivan Ali ${ }^{1}$, Riskha Amaliya Lubis $^{2}$ and Anis Mashdurohatun ${ }^{3}$
}

\begin{abstract}
Deregistration in the legal dictionary means deletion. The deletion in question is the abolishment of the mortgage right on the land title book and the certificate. If the mortgage right is removed, the Land Office shall make deregistration (Deletion/Roya) to the record of mortgage rights on the land title book and its certificates. The method used by the writer in this research was sociological juridical research, with descriptive analytical research specification, while the data analysis method used was qualitative analysis. Based on the results of the study and discussion, it can be concluded that the Deregistration Consent Agreement is as a statement from the debtor in notarial, the content is about the debtor has paid off the debt and the creditor agreed to remove the certificate of land rights burdened by the Guaranteed Right to be a clean certificate of any engagement. The Deregistration Consent Agreement does not have the executorial power as the Mortgage Right Certificate. The authority of a Notary in making the Deregistration Consent Agreement shall be based on the statement of the debtor before the Notary, so that the statement or agreement is conveyed by the Notary in an authentic agreement. This is in accordance with the provisions of Article 15 paragraph (1) of Act No.2 Of 2014 on Amendment to Act No.30 Of 2004 regarding Notary Position.

Keywords: Public Notary; Agreement; Mortgage Rights.
\end{abstract}

\section{Introduction}

The rapid development of technology and information has changed the various aspects of business behavior and economic of the world. With these developments, the field of law was required to be able to compensate, Law required to be able to align itself to the phenomenon of cooperation, the goal is for the sake of mutual prosperity. Indonesian law must also be able to anticipate the effects of new developments and other new orders that are now moving in changes.

These new developments are increasingly linking with the needs of society to the existing laws, for example people are beginning to no longer recognize agreements based on mutual trust as they first knew. Any agreement made by the community will lead to a means of achieving legitimacy, ie, by their written agreement they can have powerful evidence when a problem occurs. The necessity of these written agreements was made to ensure legal certainty for all parties.

In the provision of Article 1865 Civil Code can be used as evidences in the form of authentic agreement or underhand agreement. Authentic agreements are agreements made by officers authorized for it by authorities in accordance with established provisions, whether with or without the assistance of interested parties, it records what is requested

\footnotetext{
${ }^{1}$ Student of Master Program (S2) of Notaries Faculty of Law Universitas Islam Sultan Agung email gholibivan@gmail.com

2 Students of Master of Law, Faculty of Law, Universitas Islam Sultan Agung email riskha.yulianto@gmail.com

${ }^{3}$ Lecturer of Faculty of Law UNISSULA
} 
to be published therein by interested parties. The authentic agreement ${ }^{4}$ contains the statement of an official explaining what is done or seen before him. Officials authorized to make an authentic agreement, one of them is called Notary.

The presence of a Notary is desired by the rule of law with a view to assisting and serving people who require authentic written evidence of circumstances, events or legal acts. ${ }^{5}$

Notary has his own authority which is not owned by other state official. It has the authority to make authentic agreement of all acts, agreements and statutes required by law and/or desired by interested parties to be stated in authentic agreement, guarantee certainty the making of agreements, prescribe agreements, giving grosses, copies and citations of agreements. All of those actions are not also assigned or excluded to other officers or persons stipulated by law as provided in Article 15 paragraph (1) Of Act No.2 Of 2014 on Amendment to Act No.30 Of 2004 Concerning Position of Notary (hereinafter referred to as UUJN Act). An authentic agreement made by a notary is a proving tool to declare a legal act perpetrated by the parties. As a proof, an authentic agreement is said to have perfect proof power.

The presence of Notaries as Public Officials who make authentic agreements is needed in various areas of community life. One of which is in the banking world, as in the making of credit agreement. Credit granting is generally done by entering into an agreement consisting of principal agreement, followed by an additional agreement in the form of a guarantee agreement. Collateral is a very closely related to the bank in the technical implementation of credit provision. Loans provided by banks need to be secured with a guarantee. Without a guarantee, the bank is difficult to avoid the risk that will come.

The purpose of collateral or guarantee is to cover the risk of loss incurred by the bank. If the customer is unable to repay the credit that has been lent, it is called as a failure credit. This means the collateral can be used as a source of repayment of credit by way of sale ${ }^{6}$. There are various goods or objects that can be used as collateral in the provision of credit and provided for in Article 1131 and Article 1132 Civil Code. In practice, the most commonly used as collateral is the material security, one of which is land and buildings that are used as collateral with mortgages right.

In Act No.5 of 1960 concerning Basic Agrarian Law (Ina: UUPA), it has been mentioned about the existence of the Deposit Insurance Institution as debt or credit guarantee, which according to Article 25, 33 and 39 of BAL (Basic Agrarian Law) stated that Property Right, Right to Use and (Building Right) can be used as debt with burden of Mortgage Right. The binding of the credit guarantee with the Mortgage right is made when a customer or debtor obtaining credit from the bank makes the immoveable land (land rights) and the objects related to the land as collateral without the debtor handing over the land physically to the creditor (bank). Thus, the ownership rights of the land remain with the original owner or the Depositary, while the Bank only has a Deposit Rights that grants the right to receive repayment of its receivables from other creditors. The implementation of this warranty agreement is a series of a principal agreement, namely credit agreement. Therefore, the implementation of the guarantee binding can only be done after the credit agreement is settled

Although there is already a Credit Agreement and Agreement of Mortgage Right that

\footnotetext{
${ }^{4}$ Husni Thamrin 2011 Pembuatan Akta Pertanahan oleh Notaris Laksbang Pressindo Yogyakarta $\mathrm{p}$ 11.

${ }^{5}$ Habib Adjie 2011 Hukum Notaris Indonesia (Tematic Interpretation on Act. No.30 of 2004 On Public Notary Refika Aditama Bandung p 14.

${ }^{6}$ http://www.akuntansilengkap.com/perbankan/pengertian-agunan-jaminan-beserta-tujuan-danasas-asas/accessed on 23 April 2018 at 22.00.
} 
Volume 5 Issue 2, June 2018

states, the object of land rights is guaranteed against the debt of the right holder. In the certificate, there is no record about this agreement, because the person who has the right to register it is the National Land Agency through the Land Office in each region. It has been regulated in Article 13 of the Mortgage Rights Act, the Granting of Insurance Rights must be registered with the Land Office. No later than 7 (seven) working days after signing the Agreement of Mortgage Rights, PPAT (Land Agreement Official) shall be obliged to send the Agreement of Assignment of the related Mortgage and other necessary Warkah to the Land Office.

If the credit process between the debtor and the banking party has been settled, the debtor has paid off his debts, the bank shall issue a Certificate of "Paid' and a Deregistration (Ina; Roya) Letter addressed to the Head of the Land Office containing a request for immediate deletion of the Mortgage record. With the issuance of Deregistration Letter, all the files, including the original certificate and the Certificate of Deposit Rights are returned to the owner. Furthermore, the owner may request the deletion of the certified records concerning the imposition of the Deposit Rights or the imposition of the debt to the Land Office.

In the legal dictionary, Deregistration (Roya) means deletion. Deregistration mortgages are regulated in Article 22 of Act No.4 Of 1996 concerning Land and Property Rights related to Land. Deregistration is the deletion of mortgage rights on land titles and certificates. If the mortgage is removed, the Land Office shall make Deregistration to the record of mortgage rights on the land title book and its certificates. Certificate of Deposit Rights shall be declared null and void by the Land Office. ${ }^{7}$

The registration of the deletion of the Deposit Rights shall be conducted by the Head of the Land Office by deleting the records of the relevant mortgage rights on the land books and the object certificates as collateral. The deletion of such records shall be based on an application from an interested party within 7 (seven) working days of the receipt of the application by the Land Office. ${ }^{8}$

The Deregistration Consent Agreement is usually made by a Notary at the request of the creditor by attaching a letter of loss from the police office containing the statement that the debtor's mortgage certificate under his/her authority is declared lost. The Certificate of Mortgage is a condition for the debtor who has repaid the debt to make Deregistration. Despite being a Notary's authority, the making of the Deregistration Consent Certificate has not been specifically regulated. In the Notary Law, there is no mention of the Deregistration Consent Agreement. However, if it refers to Article 15 paragraph (1) UUJN the authority of a Notary in making authentic agreements, then the making of the Deregistration Consent Certificate as one of the authentic agreements can be done by a Notary.

Based on the description above, the authors want to examine more about the problems and arrange them in the form of a thesis with the title: Authority of Notary in Making Deregistration Consent Agreement in Lieu of Certificate of Mortgage Right

\section{Research Methods}

The method used by the writer in this research was sociological juridical research method.

\footnotetext{
${ }^{7}$ Efty Hindaru Sudibyo Peran Notaris dalam Pembuatan Akta Izin Roya Hak Tanggungan Karena Hapusnya Hutang dalam Perspektif Kepastian Hukum, Jurnal Akta, Volume 4 No 2 June 2017

${ }^{8}$ Sutardja Sudrajat 1997 Pendaftaran Hak Tanggungan dan Penerbilan Sertiftkatnya Mandar Maju Bandung p 54.
} 
Tamahana stated that socio-legal studies are addressed to Law and Society Studies ${ }^{9}$ According to F.X. Adji Samekto, Social legal studies conceptualize law as the norm and simultaneously as reality. The sociological juridical approach is a legal research using secondary data as the initial data, followed by primary data or field data examining the effectiveness of a law and research seeking correlation between various symptoms or variables as a data gathering tool comprising a study documents, observation and interview. ${ }^{10}$

The specification used in this research was descriptive analysis. It is research which give overview, write and report an object or an event, also take general conclusion from problem which is discussed.

Types of data used in this study were primary and secondary data. Data analysis method used in this research was qualitative method. After the data were collected and then described in the form of logical and systematic description. Moreover, the data were analyzed to obtain clarity of problem solving, so it could be drawn a deductively deduced conclusion-from general to specific thing.

\section{Result And Discussion}

Government Regulation No. 24 of 1997 on the registration of land mentions that the land registration is carried out on the basis of simple, safe, affordable, current and open principles. Therefore, the registration of the Mortgages Right deletion shall be executed on the basis of the principles laid down in the land registration system. According to the provisions of Article 3, PP No.24 of 1997, land registration aims:

- to provide legal certainty and legal protection to the rights holder of a land, apartment units and other registered rights so as to easily prove him/herself as the holder of the rights concerned.

- to provide information to the interested parties including the Government in order to easily obtain the necessary data in the conduct of legal acts concerning the plots of land and apartment units already registered;

- to implement the orderly administration of land.

However, in practice, there are debtors who have paid their debts to the bank and have got Deregistration Letter, Certificate of Mortgage Rights and Certificate of land rights, do not filed Deregistration in the Land Office because they do not understand the function of Deregistration (Roya). It is strongly recommended that the bank provide an explanation of what Deregistration is, in order for the settlement to be followed up with an administrative settlement at the Land Office. Further, if the Certificate of Mortgage Right has disappeared, for the removal of the load record (Deregistration), the Land Office usually advises the debtor immediately make a Deregistration Consent agreement before a Public Notary.

The Deregistration Consent Agreement in the Mortgage Act is not specifically explained. The Deregistration Consent is a statement of approval for making Deregistration, which is usually used to replace the lost Mortgage Certificate. The Deregistration Consent Agreement can be regarded as an authentic agreement because it is made before the Public Notary Officer. Therefore, it has perfect proof power.

Agreement made before or by Notary shall be domiciled as an authentic agreement according to the form and procedure stipulated in the Law of Notary Position, this is in

\footnotetext{
${ }^{9}$ Anis Mashdurohatun, Redyanto Sidji, Gunarto and Mahmutarom, Factors Causing Banking Cyber Crime in Indonesian, International Journal of Economic Research, Volume 14 Number 15 2017, p.295

${ }^{10}$ Amiruddin 2012 Pengantar Metode Penelitian Hukum Raja Grafindo Persada Jakarta p 22.
} 
accordance with the opinion of Philipus M. Hadjon, the terms of the authentic agreement are: ${ }^{11}$

- In the form prescribed by the Act (standard form);

- Made by and in the presence of the General Officer;

Article $1868 \mathrm{BW}$ is the source for the authenticity of notarial agreement, it is also the basis of the legality of the existence of notarial agreement, with the following conditions: ${ }^{12}$

- The agreement must be made by (door) or before (ten overstaan) a Public Official;

- Agreement must be made in the form prescribed by the Act;

- Public Officials by or before to whom the agreement is created shall have the authority to make such agreement;

The Deregistration Consent Agreement is a Partij agreement or also referred to as the Agreement of the Party, which is made before the Notary at the request of the debtor as party. It contains a statement that the Mortgages Rights Certificate in whose power the debtor has disappeared, where the Mortgages Certificate is a requirement for debtors who have paid his debt to do deregistration.

\subsection{The Authority Of Public Notary In The Making Of Deregistration Agreement Of Mortgage Right}

Notary has the authority to make authentic agreements at the request of the parties for all acts (law), including the Deregistration Consent Agreement which is one of the authentic agreements made by the Notary at the request of the Depositary. It contains the statement of the party of the Depositors (debtors) that the Certificate of Mortgage which is in his power has been lost, where the Certificate of Mortgage is a requirement for the debtor who has paid his debts for Deregistration. This is in accordance with the provisions of Article 15 paragraph (1) and (2) of Act No.2 of 2014 on the Second Amendment to Act No.30 Of 2004 About Position Notary, namely:

- Notaries are authorized to make authentic agreements of all agreements, agreements and statutes required by legislation and/or desired by interested parties to be declared in an authentic agreement, guarantee the date of making the agreement, preserve the agreement, grant, copy and excerpts of agreements, all of which during the making of the agreement are not also assigned or excluded to other officials or other persons as defined by law.

- In addition to the authority referred to in paragraph (1), the Notary is also authorized to: authorize signatures and specify the date of the letter under the hand by registering in a special book; record the letters under the hand by registering in a special book; make a copy of the original letter under the hand in the form of a copy containing the description as written and illustrated in the letter concerned; validate a photocopy match with the original letter; provide legal counseling in relation to the making of the agreement; make agreement related to land; or make a agreement of auction.

Based on those points, the Deregistration Permit Agreement is not made by the Land Office, Bank or PPAT (Land Titles Registrar). Although if we observe more, it directs to issues related to land so that more appropriate for the Land Office or PPAT (Land Titles Registrar) to make the agreement. However, such matter is not an excuse not to be made by notarial agreement because the Notary is authorized to make agreement related to the

\footnotetext{
${ }^{11}$ Habib Adjie I Op.cit p 56

${ }^{12}$ Ibid $p$ 56-57
} 
land as long as it is not the authority that already exists in PPAT (Land Titles Registrar). ${ }^{13}$ Conditions for making a Deregistration Consent Agreement on a Notary Office for the debtors who have lost the certificate of Mortgage Rights are: Evidence of loss of the certificate of Mortgage Rights from the Police Office; There shall be evidence of debt repayment from the creditor; The description of the debtor is true that he has lost the certificate of Mortgage Rights

\section{Closing}

\subsection{Conclusion}

The conclusions are as follows:

- The Agreement of Consent Deregistration is a notarized statement by the debtor, whose debtor has been settled from the debts and the creditor agrees to abolish the certificate of land rights burdened by the Mortgages Right into a clean certificate of any engagement. The Deregistration Consent Agreement does not have the executorial power as well as the Certificate of Mortgage Rights.

- Authority of Notary in making the Deregistration Consent Agreement is based on the statement of the debtor before the Notary, so that the information or agreement is conveyed by the Notary in an authentic agreement. This is in accordance with the provisions of Article 15 paragraph (1) of Act No.2 Of 2014 on Amendment to Act No.30 Of 2004 regarding Notary Position.

\subsection{Suggestion}

- National Land Agency office should make strict rules regarding the period of time if the debtor who has received back the certificate of land rights and certificate of mortgage from the creditor. If they do not immediately make Deregistration of Mortgage Right, they will be sanctioned. It is to avoid the debtor is not negligent to immediately waive the certificate of rights to his land and also to avoid the loss of the certificate of Mortgage Rights.

- For creditors or Banks, for the sake of justice, Deregistration should be charged by the creditor (bank) because the bank temporarily holds the certificate of land rights owned by the debtor as collateral. Once the debtor repays the debt, the creditor may immediately propose the Deregistration, so that the certificate of rights to land later submitted by the creditor to the debtor in a clean condition is not attached to any burden, because when the debtor handed over the land certificate to the bank as collateral was in clean condition.

- For the public, especially debtors who have paid off their credit in the Bank, they should immediately conduct the Deregistration, in order to avoid the things that can be detrimental, namely the loss of Certificate of Mortgages Rights or the loss of Deregistration Letter.

\section{References}

[1] Amiruddin 2012 Pengantar Metode Penelitian Hukum Raja Grafindo Persada Jakarta.

[2] Anis Mashdurohatun, Redyanto Sidji, Gunarto and Mahmutarom, Factors Causing Banking Cyber Crime in Indonesian, International Journal of Economic Research, Volume 14 Number 152017

[3] Efty Hindaru Sudibyo Peran Notaris dalam Pembuatan Akta Izin Roya Hak Tanggungan karena hapusnya hutang dalam Perspektif Kepastian Hukum, Jurnal Akta, Volume 4 No 2 June 2017

${ }^{13}$ Rudi Indrajaya and Ika Ikmasari 2016 Kedudukan Akta Izin Roya Hak Tanggungan Sebagai Pengganti Sertifikat Hak Tanggungan Yang Hilang Visimedia South of Jakarta p 56-57 
Volume 5 Issue 2, June 2018

[4] Habib Adjie 2011 Hukum Notaris Indonesia (Tematic Interpretation on Act. No.30 of 2004 On Public Notary Refika Aditama Bandung.

[5] Husni Thamrin 2011 Pembuatan Akta Pertanahan oleh Notaris Laksbang Pressindo Yogyakarta.

[6] Rudi Indrajaya dan Ika Ikmasari 2016 Kedudukan Akta Izin Roya Hak Tanggungan Sebagai Pengganti Sertifikat Hak Tanggungan Yang Hilang Visimedia South of Jakarta.

[7] Sutardja Sudrajat 1997 Pendaftaran Hak Tanggungan dan Penerbilan Sertiftkatnya Mandar Maju Bandung. 